\title{
Intensifying Language Learning Through Practice: Role-Play and The Perceptions of Japanese Medical- Related Profession Students
}

\author{
Faramarz Samifanni, Ed. D. ${ }^{1}$ \\ ${ }^{1}$ Fukuoka International University of Health and Welfare \\ Fukuoka, Japan \\ Email:fredsami@takagigakuen.ac.jp
}

\begin{abstract}
This article presents a descriptive mixed study regarding the perceptions of university medical-related profession students towards role-playing and their confidence in communication. Students' perception towards roleplaying was determined by an open-ended questionnaire while their most important consideration in language study was measured through a seven-point Likert scale. Thematic analysis was used for the qualitative data while descriptive statistics were used to analyze quantitative data. Out of the 144 students from all the classes, 117 medicalrelated profession students participated in the study. Results showed that role-playing helped the students gain confidence through frequent practice of the target language. Moreover, role-playing showed improvement in the medical-related students' oral communication skills including their non-verbal communication skills. Furthermore, the students consider practicing the target language as the most important consideration in language study. The results indicate that this study can provide substantial data towards a new approach and a paradigm shift in English language education at the university level; from grammar focused instruction to communicative approach.
\end{abstract}

Keywords - confidence, communication skills, practice role-play

\section{INTRODUCTION}

The recent result of the EF English Proficiency Index ranked Japan 53rd out of the100 countries included in the report. A score of 51.51 includes the country in the low proficiency level [1]. Though the country has been in this bracket since 2016, this is the lowest ranking Japan had since the country's participation in 2011.

Before enrolling in a university, Japanese students undergo English instruction at least six years in junior and senior high school [2]. This notion has even increased New English Education corresponding to globalization. However, the lengthy period of English education is not enough for university students to use English as desired [3]. Although universities are increasing their English proficiency standards for entrance exams, nearly $60 \%$ of the high school population pursue university studies. Nonetheless, only half of them are required to study English for the entrance examinations. During these times, students study English only to pass the university entrance exams. They memorize vocabulary, translate Japanese sentences to English, and give importance to accuracy rather than fluency. This strategy may help students pass the examinations but could lead to the low communication ability of freshmen university students. University instructors are facing the challenge and struggle to provide a remedy to this problem. Instructors have difficulty addressing the limited vocabulary of students which hinders their reading capacity. The inadequate vocabulary of students also prohibits them from writing English sentences or communicating their thoughts to the class with ease [3].

In Japan, most native speakers are assigned the task of improving the oral communications of the students. Japanese language academia expects the native language instructors to work on students' listening and pronunciation as priorities to speaking the English language. The academe assumes that the students have had sufficient training in reading, writing, spelling, and grammar. Consequently, when the students enter a university, they become fairly tired of home-works, tests, and exams which adds to their low confidence in English communication.

\subsection{Related Literature}

Role-play slightly comprises a) role assignments to participants, and b) conveying a goal that members must achieve [4]. Role-play is a technique that assists learners to familiarize amongst themselves with the "new social environments." It is interesting for the learners to practice more genuine conditions [5]. Role-playing utilizes dynamic learning and requires learners' participation [6]. 
Although some studies mention students' reluctance towards role-playing, there are positive outcomes towards their communication skills. For instance, due to past learning experiences, role-playing may not be a normal activity in Japanese EFL classes because English language teaching is focused on form and activities are in a controlled setting. Also, due to their fear of error, some students do not have the attitude to learn English and not take the role-play seriously. Nevertheless, effective role-plays convert the class into a "more fun and exciting place" [7]. Ardriyati [8] suggested that role-play can enable a lively and organized "speaking-focused" class. Although the students might have doubts and lacked confidence, role-play can help to achieve the class's goals.

The researcher noticed many English language instructors used various approaches that did not guarantee students' equal speaking opportunities in class; making the students less confident of their English-speaking skills upon entering university. These factors were the main consideration that prompted the conduct of this study.

While prior researches were conducted concentrating on integrating role-play to the instruction in language classes, the present article provides a fresh view in the role-play utilization in encouraging the confidence and communication skills in the Japanese university context.

\subsection{Objectives of the Study}

This study assessed the viewpoint of Japanese medical-related profession students regarding their confidence in communication through role-playing. Accordingly, this paper intended to answer these research questions:

RQ1: What is the effect of role-playing in building the students' confidence?

RQ2: Do learners see improvement in their communication skills through role-playing?

RQ3: What is the most important consideration in learning a second or a foreign language?

\section{MATERIALS AND METHODS}

\subsection{For the course}

Within the Second semester of the academic year 2019-2020, the entire English language classes that the researcher / instructor was handling were role-play based. Freshmen learners between 18 and 21 years of age were enrolled in varied medical-related profession courses at the university. Based on their English skills placement test result (that the researcher / instructor made and administered), the students" "English language proficiency level" ranged from beginner to intermediate level respectively. All students spoke Japanese as their first language (L1) and practiced English as a Foreign Language (EFL), respectively.

The researcher / instructor gave four preliminary lessons before starting with the actual lessons. In the fourth session, the students took a teacher-made placement test.

During the fifth lesson / session, the different groups were formed for their role-play performances. From here onwards, the lessons would focus on professional English conversation. Since the students cannot produce their script from a given situation in a limited time, it was decided that they will be provided scripts (sample script). After script distribution, the researcher / instructor reads the script once, and on the second time, the students will repeat after $\mathrm{him} /$ her. It is emphasized to imitate the proper pronunciation of the words. The groups are given 15 minutes to familiarize and rehearse. Afterward, the groups perform in front of the class without

Meeting a new patient (sample script- occupational therapy)

OT: Good morning, I'm Junya, your occupational therapist.

Patient: Oh, nice to meet you I'm Sato.

OT: Would you give me a background of your condition?

Patient: I had a hip fracture and it's hard for me to sit.

OT: I see; can you show me how you move around?

Patient: Okay.

The groups volunteer on who would perform first. There never had a situation where they did not want to perform or even me choosing the group to get to perform. Subsequently, the researcher / instructor gives comments based on performances as well as encouraging the students with a strong notion saying to students: "Make no mistake; you are good but I want you to be GREAT."

The researcher / instructor keeps a record of students' participation in the role-play activities to recognize students' weaknesses, pronunciation, and communication problems relating to imitation and practice. This is used for assisting the 
students in improving their communication skills.

\subsection{For the study}

A questionnaire consisted of two parts: for the qualitative part, the participants were asked to answer an open-ended essay question: What can you say about role-playing and your confidence in communicating? コミュニケーションにおいてロールプレイングとあなたの自信についての考えを教えて下さい? Second，was a 7-point Likert-scale questionnaire that asked the students about their top consideration in learning a second or foreign language adopted from [9].

\subsection{Research Design}

To address the research questions, a descriptive mixed study was employed to provide an in-depth analysis of the data on the medical-related profession students' perception towards role-playing and their confidence in communication, and their consideration in language study.

\subsection{Data collection}

Data were collected from eight English language classes from a private medical university within Kyushu area. There were 144 students in all eight classes; 76 males and 68 females. However, only 117 responses were considered for the study because some were absent and others did not follow the instructions for the survey. All students were non-English majors who were taking the subject as a course requirement. From the eight classes, two of the classes were elective subjects. For ethical considerations before the conduct of the study, consents were secured from the students and they were informed that any data collected would be handled with utmost confidentiality and anonymity for the sole purpose of research.

\subsection{Data Analysis}

Thematic analysis [10] was used to categorize and identify recurring themes from the obtained data for the qualitative part. The responses were coded and interpreted to categorize and discover significant and recurring themes. Four categories were identified (Table 1), wherein themes regarding the students' confidence and communication skills; gain of students' confidence, improved communication skills emerged. Moreover, descriptive statistics were used to analyze quantitative data. To guarantee the reliability, the researcher and a colleague completed a parallel analysis of the data and discussed discrepancies until reaching a consensus. The original Japanese responses have been translated into English by a native Japanese speaker.

\section{MAIN TEXT}

The responses of the participants generated a total of 144 total units from the open-ended question. Data analysis identified the following categories: confidence and communication skills (105), Factors affecting confidence (17), Roleplay and real-life application (10), Others (12); see Table 1 for reference. The items in "others" consisted of irrelevant answers from respondents, for example, the use of one's imagination to gain confidence, which is not related to the focus of the study were not considered for analysis. Emergent themes concerning the gain of confidence through practice (74) and improved communication skills (21), along with the students' consideration in studying a foreign language (Table 2) will be reported. Representative students' comments are found in the Appendix.

Table 1: Category and themes of participants' responses

\begin{tabular}{lll}
\hline Category & Theme \\
\hline 1. Confidence and communication skills (105) & Gain of confidence through practice (74), \\
& $\begin{array}{l}\text { Improved communication skills (21), Did not improve confidence } \\
(9)\end{array}$ \\
& $\begin{array}{l}\text { Partner preference/familiarity (3); } \\
\text { 2. Factors affecting confidence (17) }\end{array}$ & Understanding the context (2); Material's level of complexity (2); \\
& Value of confidence (1); Necessity for more practice (7); Effort \\
& $(1) ;$ Disinterest (1) \\
3. Role-play and real-life application (10) & Importance of role-play (5); Real-life application (5) \\
4. Others (12) & - \\
Total (144) &
\end{tabular}

\subsection{Gain of confidence through practice}

The students seem to agree that frequent performances of role-playing help them gain their confidence in using the English language before their classmates. A remarkable 74 units from the emergent themes suggested that if students keep practicing the target language in class, they will gain their confidence. The students felt that performing role-play "so many times" helped them gain confidence. One student even had a formula for gaining confidence: "Role-playing: 
practice + keep practicing = confidence up." Although medical-related profession students felt unwilling and shy during their first role-play performance, after several times, they became accustomed to it and noticed that they have gained their confidence speaking in English. Their repetitive hands-on exposure to the English language and the positive reception of their classmates during performance contributed to their confidence and active participation in class. Some of the students reported that the constant practice of the English language through role-playing helped them to "gradually" gain their confidence. They consider role-playing during class as a "good experience." The sense of accomplishment after a satisfactory role-playing performance help enhance their confidence. The positivity made the students strive harder and exert more effort especially communicating in English and for their future performances. Nevertheless, when students fail to deliver a good performance, they consider their teacher's corrective feedback helpful in furnishing their weak points. This makes them improve their future performances. Furthermore, the students believe that they can successfully communicate with their future possible None-Japanese speaking patients with confidence using English as a tool. This is because they frequently use the target language during role-playing and overcome stage fright.

\subsection{Improved communication skills}

The series of role-playing performances made medical-related profession students feel that they can confidently communicate in English. A notable 21 units from the themes emphasized this positive effect of role-playing on their communication skills. Some reported that the activity also helped them improve their pronunciation, accent, and fluency. Others stated that they were able to communicate in longer sentences and read English through role-playing. Roleplaying also enabled the students to enhance their non-verbal communication skills. The once shy students can now establish eye-contact while performing and portray appropriate facial expressions.

\subsection{Consideration in studying a foreign language}

Table 2. Students' consideration in studying a foreign language

\begin{tabular}{|c|c|c|c|c|c|c|c|c|c|}
\hline \multirow[t]{2}{*}{ Consideration } & \multirow[t]{2}{*}{$\begin{array}{c}\text { Most } \\
\text { Important }\end{array}$} & \multirow[t]{2}{*}{ Important } & \multirow[t]{2}{*}{$\begin{array}{l}\text { Somewhat } \\
\text { important }\end{array}$} & \multirow{2}{*}{$\begin{array}{c}\text { Neither } \\
\text { important } \\
\text { nor } \\
\text { unimportant }\end{array}$} & \multirow{2}{*}{$\begin{array}{c}\text { Somewhat } \\
\text { Not } \\
\text { Important }\end{array}$} & \multirow[t]{2}{*}{$\begin{array}{c}\text { Not } \\
\text { Important }\end{array}$} & \multirow{2}{*}{$\begin{array}{c}\text { Not } \\
\text { Important } \\
\text { at all }\end{array}$} & \multicolumn{2}{|c|}{$\begin{array}{c}\text { Total } \\
\text { Response }\end{array}$} \\
\hline & & & & & & & & No & $\%$ \\
\hline $\begin{array}{l}\text { Reading, Writing } \\
\text { and Grammar }\end{array}$ & $27 \%$ & $32 \%$ & $12 \%$ & $14 \%$ & $10 \%$ & $3 \%$ & $2 \%$ & 117 & $100 \%$ \\
\hline Practicing & $58 \%$ & $25 \%$ & $12 \%$ & $4 \%$ & $2 \%$ & $0.2 \%$ & $0.02 \%$ & 117 & $100 \%$ \\
\hline Culture of TL & $31 \%$ & $22 \%$ & $18 \%$ & $12 \%$ & $9 \%$ & $5 \%$ & $3 \%$ & 117 & $100 \%$ \\
\hline Accent & $11 \%$ & $21 \%$ & $28 \%$ & $20 \%$ & $13 \%$ & $6 \%$ & $0.6 \%$ & 117 & $100 \%$ \\
\hline Listening & $31 \%$ & $35 \%$ & $22 \%$ & $8 \%$ & $2 \%$ & $1 \%$ & $0.03 \%$ & 117 & $100 \%$ \\
\hline Imitating & $34 \%$ & $27 \%$ & $18 \%$ & $15 \%$ & $4 \%$ & $0.7 \%$ & $0.1 \%$ & 117 & $100 \%$ \\
\hline Motivation & $41 \%$ & $17 \%$ & $9 \%$ & $12 \%$ & $11 \%$ & $9 \%$ & $1 \%$ & 117 & $100 \%$ \\
\hline
\end{tabular}

As represented in table 2, the students gave high consideration to practicing (58\%) as being the most important in studying a foreign language; this is followed by motivation (41\%). Meanwhile, the culture of the target language (3\%) is not given importance by medical-related profession students whenever they study a foreign language. This implies that students primarily value their ability to communicate and express their ideas by practicing the target language especially in their future profession where clear communication to future patients is imperative.

In this study, role-playing is the avenue for the medical-related profession students to constantly practice the English language which helped them gain their confidence to communicate their ideas and improve their verbal and non-verbal communication skills.

The findings highlighted that the students' high frequency of exposure to the target language through role-playing made them gain their confidence. The opportunity provided for the students to constantly practice the target language in every class session, and this led them to overcome their fears and eventually getting accustomed to the activity. The students' feeling of being "used to" role-playing made them deliver a good and satisfactory performance which gives them a good experience and eventually enhances their confidence. Furthermore, the instructor's corrective feedback motivated the students to perform better. This is similar to the study where children improved their confidence through role-plays [11] as well as feeling confident and "work-ready" [12]. It was found that learning is improved when learners do make mistakes. Error-making is how learners are challenged to learn to do things another way. Making errors motivates learners to try new ways [13]. It seemed that the shy learners were able to overcome their fears and "remove their shyness" as shown in the study of Bashir, Azeem, \& Dogar [14] through their frequent role-playing performances. Students became risk-takers and exerted much effort to deliver their best performance every time. Johnson [15] considered that risk-takers are also better in learning than non-risk-takers. Through role-playing, the instructor seemed "to encourage" the students to take the risk to join and perform the role-plays and the activity yielded positive results, especially to the students' confidence. 
Moreover, it seemed that the students have seen an improvement in their communication skills, particularly in their pronunciation and non-verbal skills after frequent role-play performances. This finding is similar to studies where roleplay was found effective in teaching speaking [16] and improving their communication skills [17]. The findings are partially similar to another study [18] however, the current study highlighted the students' improvement in their nonverbal communication skills. The findings are also similar to prior studies [19-21] which highlighted the improvement of confidence and communication skills of students through role-playing. The authentic or real-life tasks in role-playing enable productive language teaching which resulted to the gain of confidence and improved communication skills of the students [22]. Role-play provides a "rewarding" experience not only to the students but also to instructors [23].

Medical-related professional students consider practice as the most important consideration in studying a language. This means that the main goal of these students is to orally communicate with their possible future patients. For practical reasons, their future profession will not be requiring them to study the technical aspects of the English language; instead, it would require them to communicate with clarity and confidence to their patients. The students see English as a tool and not a set of rules because mastery of the rules will be impractical if they fail to communicate effectively.

Language learning is much easier if one is interacting with people who are using the target language. This implies that the learner can discover how to say and use the language more naturally and natively. In role-plays, practicing the right possible situation dialogues are important and ensures that the correct repetition of the skill is vital in language learning. Language learners should keep in mind that the frequency of practice, plays a vital part in learning a language and thus they should use the learned vocabularies of the target language frequently. Based on the facts presented in this study, practicing the target language through role-playing also ensures the fluency and continuity of the language learned as a skill. Learning a language is equal to risking one's face because of the linguistic and cultural considerations that must be achieved. Instructors should motivate the students despite their flaws during performances. Once the learners are logically convinced that imitation and practice during role-playing have made them speak a certain point fluently, their self-motivation increased with their feeling of accomplishment leading to self-confidence and improved communication skills. For medical-related profession students, improved communication skills are vital for the trust required from the client and the professional relation.

\section{ACKNOWLEDGEMENT}

My deepest gratitude the Creator of all Good Thoughts, Good Words and Good Deeds as well as to the leaders of Fukuoka International University of Health and Welfare, Director/Owner Doctor Kunihiro Takagi, President/Doctor Tsutomu Imaizumi, Vice-president/Doctor Hitoshi Maruyama and the Department Heads for their moral support and positivity in allowing me to improve the students' language communication skills. Also, a special thanks to the respondents, who were kind enough to give consent to their participation in this research.

-Faramarz Samifanni, Ed. D.

\section{REFERENCES}

[1] EF EPI, "The world's largest ranking of countries and regions by English skills," https://www.ef.com/wwen/epi/. 2019.

[2] MEXT, "English Education Reform Plan corresponding to Globalization," https://www.mext.go.jp/en/news/topics/detail/_icsFiles/afieldfile/2014/01/23/1343591_1.pdf. 2014.

[3] A. Ikegashira, Y. Morita and Y. Matsumoto, "English Education in Japan: From Kindergarten to University," in Into the Next Decade with (2nd) FL Teaching, Matsuyama, Japan, Rudolf Reinelt Research Laboratory EU, pp. 16-40, 2009.

[4] H. D. Brown, Teaching by Principles: An, NY: Addison Wesley Longman, p. 183, 2001.

[5] P. R. Shankar, R. M. Piryani, K. K. Singh and B. M. Karki, "Student feedback about the use of role plays in Sparshanam, a medical humanities module," F1000Research, vol. 1, no. 65, 2012.

[6] G. Schumann, "Enhanced Learning through Role-Playing," The Plant Health Instructor, 2002.

[7] E. Bray, "Doing role-play successfully in Japanese language classrooms," The Language Teacher, pp. 13-18, 2010.

[8] W. Ardriyati, "Roleplay: One Alternative And Effective Teaching Method To Improve Students' Communicative Skill," Dinamika Bahasa \& Budaya, vol. 3, no. 2, pp. 218-228, 2009. 
[9] R. A. Begum and J. J. Pereira, "Business and Climate Change Issues: Discussion on Awareness and Motivational Factors," in Proceedings of Global Accounting, Finance and Economics Conference, Melbourne, Australia, 2012.

[10] J. Creswell, Qualitative Inquiry \& Research Design: Choosing Among the Five Approaches, Thousand Oaks, CA: SAGE Publications, Inc., 2013.

[11] G. C. J. Kress and M. A. Ehrlichs, "Development of Confidence in Child Behavior Management through Role Playing," Journal of Dental Education, vol. 54, no. 10, pp. 619-622, 1990.

[12] J. Howieson and S. L. Rogers, "Using the role-play at the lectern: developing "work-ready" and confident professionals," The Law Teacher, 2017.

[13] M. Price-Mitchell, "Mistakes Improve Children's Learning," https://www.psychologytoday.com/intl/blog/themoment-youth/201109/mistakes-improve-childrens-learning. 2011.

[14] M. Bashir, M. Azeem and A. H. Dogar, "Factor Effecting Students' English Speaking Skills," British Journal of Arts and Social Sciences, vol. 2, no. 1, pp. 34-50, 2011.

[15] K. Johnson, An Introduction to Foreign Language Learning and Teaching, England : Pearson Educated Limited, 2001.

[16] A. Afdillah and M. Noor, "The Effectiveness Of Role Play in Teaching Speaking," http://repository.uinjkt.ac.id/dspace/handle/123456789/26710. 2015.

[17] R. A. Ampatuan and A. S. Jose, "Role Play As An Approach In Developing Students' Communicative Competence," International Journal for Innovation Education and Research, vol. 4, no. 1, pp. 18-24, 2016.

[18] N. A. b. A. Rahman and N. Maarof, "The Effect of Role-Play and Simulation Approach on Enhancing ESL Oral Communication Skills," International Journal of Research in English Education, vol. 3, no. 3, pp. 63-71, 2018.

[19] F. Lestari and F. A. Sridatun, "An Analysis of Student Speaking Skill Using Role Play Method," Professional Journal of English Education, vol. 3, no. 1, pp. 114-119, 2020.

[20] T. Lestari, E. H. Mulyana, I. Nurzaman, G. Gandana and E. Apriyaningsih, "Exploring the integrating potentials of role playing with YouTube in building student's self confidence," Journal of Physics: Conference Series, vol. 1318 , pp. 1-7, 2019.

[21] J. Dohaney, E. Brogt, T. M. Wilson and B. Kennedy, "Using Role-Play to ImproveStudents Confidence and Perceptions of Communication in a Simulated Volcanic Crisis," in Observing the Volcano World. Advances in Volcanology (An Official Book Series of the International Association of Volcanology and Chemistry of the Earth's Interior - IAVCEI, Barcelona, Spain), Barcelona, Springer, Cham, pp. 1-24, 2017.

[22] Author, "The Fluency Way: A Functional Method for Oral Communication. English Language Teaching," English Language Teaching, vol. 13, no. 3, pp. 100-114, 2020.

[23] P. K. Tompkins, "Role Playing/Simulation," The Internet TESL Journal, vol. 4, no. 8, 1998. 